\title{
The EFFeCt OF INTERNet PIRACY ON CD SALES: CROSS-SECTION EVIDENCE
}

\author{
MARTIN PEITZ \\ PATRICK WAELBROECK
}

CESIFO WORKING PAPER NO. 1122

CATEGORY 9: INDUSTRIAL ORGANISATION

JANUARY 2004
An electronic version of the paper may be downloaded - from the SSRN website:
- from the CESifo website:
www.SSRN.com
www.CESifo.de




\title{
The EFFeCt OF InTERnet Piracy ON CD SALES: CROSS-SECTION EVIDENCE
}

\begin{abstract}
We analyze the role of music downloading on the current downturn in CD sales. We provide 2000-2001 cross-country evidence in support of the claim of losses due to internet piracy made by the music industry. For the U.S. we also assess the potential loss from internet piracy using detailed survey data. We conclude the empirical analysis by forecasting CD sales for 2002. The results suggest that internet piracy played a significant role in the decline in CD sales in 2001, but can hardly account for the subsequent drop in 2002.
\end{abstract}

JEL Classification: D12, L82.

Keywords: piracy, music, peer-to-peer, internet, survey data, cross-country regressions.

\author{
Martin Peitz \\ Department of Economics \\ University of Mannheim \\ 68131 Mannheim \\ Germany \\ peitz@bigfoot.de
}

Patrick Waelbroeck ECARES

Free University of Brussels

CP 114, 50 av. Roosevelt 1050 Brussels

Belgium

pwaelbro@ulb.ac.be 


\section{Introduction}

Many voices in the music industry have claimed that internet piracy has reduced sales of legitimate CDs and that illegal MP3 downloads have become a substitute to legal CD purchases. ${ }^{1}$ Indeed, many analysts believe that the current downturn in CDs sales is due to the increasing and uncontrollable number of illegal copies available using peer-to-peer (P2P) technologies. Enduser piracy, which is different from for-profit piracy, seems to be much more difficult to control. The industry and policy makers have addressed this issue by reinforcing copyright laws, by implementing technological protection and by actively enforcing legal protection through lawsuits targeted at developers and users of P2P networks. Yet, defenders of online distribution technologies have argued that MP3 downloads offer a new way for consumers to try new music, a typical experience good, in order to make more informed purchases, which could increase CD sales. This is referred to as sampling or exposure effect in the economics literature. ${ }^{2}$ Thus there remains to determine the net contribution of MP3 downloads on CD sales, which is the purpose of this article.

To our knowledge, there have been only two attempts to assess the role of piracy on CD sales. Kai-Lung Hui and I.P.L. Png (2003) test the role of offline piracy on the demand for CDs.

\footnotetext{
${ }^{1}$ In the news-breaking Napster case, the court found that the use of the file-sharing technology harmed the music industry partly on the ground that illegal music download reduced legitimate sales of CDs. During the summer 2003, the Recording Industry Association of America (RIAA) started to monitor activities of file-sharing networks in preparation of a massive series of lawsuits targeting individual file-swappers. Eventually, in September 2003, the RIAA filed 261 lawsuits charging music uploaders with copyright infringement. These legal actions are also strongly based on the belief that music downloads are causing a substantial damage to the music industry. ${ }^{2}$ See Peitz and Waelbroeck (2003a) for a critical review of the literature on piracy of digital products. For a particular model that focuses on the sampling aspect, see Peitz and Waelbroeck (2003c).
} 
They test whether the demand for originals is increasing or decreasing with the extent of piracy, using international data for the period 1994-1998 covering 28 countries from the IFPI (International Federation of the Phonographic Industry), the BSA (Business Software Alliance) and the SIIA (Software and Information Industry Association) to construct measures of (offline) piracy and expected fine per country. They find a negative and significant effect on legitimate CD sales. The implied per capita demand loss is found to be 0.10 unit, $42 \%$ less than the IFPI number.

Stan Liebowitz (2003) tries to assess the effect of online piracy on the music industry. He looks at a 30-year time series of sales in the U.S. record industry using numbers by the RIAA (Recording Industry Association of America) until 2002. He argues that the current downturn in CD sales can be associated with the appearance of file-sharing technologies, although he admits that sales of other media much less substitutable to MP3 such as cassettes and singles also dropped during that period. He also dismisses the role of income and prices on CD purchases. He concludes, without using direct information on music downloads or internet usage, that "MP3 downloads are causing significant harm to the record industry".

In this article, we proceed in two steps to assess the effect of internet piracy on CD sales. First, we use data on music downloads gathered in 16 countries for the period 2000-2001 in section 2 and find a significant effect of MP3 downloads on CD sales. Second, we assess the plausibility of our estimates by analyzing survey data on MP3 downloads in the U.S. in section 3. Depending on the substitutability between MP3s and CDs and the multiplier effect of offline piracy, MP3 downloads can partly and even fully account for the CD decline in the US market in 
2001. However, using an estimated elasticity of CD sales with respect to MP3 downloads, we find that internet piracy only account for less than $25 \%$ of the CD decline in 2002 in the US. Section 4 concludes the article.

\section{Cross-section analysis}

\subsection{Factors influencing cross-section variation in $C D$ sales}

There are several factors in addition to internet piracy that could influence cross-country variation in $C D$ sales:

(1) prices;

(2) country-specific environment of the music industry, including offline piracy, taste for music, the distribution of income of potential users;

(3) income and economic environment;

(4) substitution with other media and other forms of entertainment; new distribution channels; new media such as portable CD and MP3 devices.

(5) the "quality" of music.

Liebowitz (2003) reviews these factors and finds that real prices of CDs have been quite constant over the recent years, so that factor (1) is not going to play a significant role. Price differences across countries and other countries specific factors (2) that have not changed over the period will be eliminated by taking first differences. Factor (3) will be controlled by domestic GDP. Factors in (4) will be controlled by a set of proxy variables that we will describe below. Factor (5) is unobservable and will be assumed to be uncorrelated with the internet piracy variable. 


\subsection{Data and variable description}

We use data on the music industry from the IFPI World Reports 2001 and 2002 that provide data for 2000 and 2001 respectively. It does not seem relevant to look at data prior to 1999 since filesharing technologies, a prerequisite for large-scale internet piracy, only appeared in the second half of 1999 with the creation of Napster. ${ }^{3}$ Domestic figures on music downloads have been obtained from IPSOS-REID. The 16 countries used in the empirical study represent countries with the largest markets for recorded music (in value), accounting for more than $90 \%$ of the world total CD market value. ${ }^{4}$

The dependent variable is $\underline{\mathrm{CD} \text { sales}}$, given in units of CDs sold.

Our explanatory variables are the following:

$\underline{\text { GDP }}$ (in constant dollars) captures the economic environment. ${ }^{5}$

Downloads, defined as the percentage of adult internet users who downloaded music files in MP3 format from the Internet at least once. ${ }^{6}$ This variable serves as a proxy for internet piracy but does not capture the intensity of the downloading activity: ideally, this number should be

\footnotetext{
${ }^{3}$ Although we present estimation results for the period 2000-2001 in the main text, we find the same implied effect of internet piracy on CD sales for the period 1999-2001. See Appendix 4.

${ }^{4}$ These countries are US, Japan, UK, Germany, France, Canada, Mexico, Spain, Italy, Australia, Netherlands, Sweden, South Korea, Belgium, Switzerland, and Taiwan. While we have missing observations for Austria ranked 15 in market value, Brazil (ranked 7 with $1.7 \%$ of worldwide sales) was an outlier that we discarded from the econometric analysis. Nevertheless, the partial effect of internet piracy was identical with or without Brazil, although the fit was poorer by including Brazil in the analysis.

${ }^{5}$ GDP data are from the OECD except for Taiwan for which we gathered information from the Economist Intelligence Service.

${ }^{6}$ These are survey data from the beginning of 2002 for all the countries included in our sample (documented in IPSOS-REID Tempo 2002). This is a unique dataset which gives us a powerful proxy for online piracy. Unfortunately, this restricts our analysis to a cross-section analysis.
} 
multiplied by the number of downloaded music files per user in each country. Implicitly, we assume that the effect of an additional downloader on CD sales is similar across the countries in our sample.

Broadband, defined as the number of people with home connection in percentage of the total number of households). Broadband penetration may partly capture the substitution with new forms of entertainment such as online activities, online games as well as audio-streaming and digital music distribution. ${ }^{7}$

$\underline{\mathrm{MC} \text { sales, }}$ defined as the number of units of musical cassettes (MC) sold divided by the level of CD sales (times 100). ${ }^{8}$ MC sales captures cycle effects due to the replacements of MCs by CDs: if there are proportionally many MCs compared to CDs, there is more scope for substitution between MC and CDs. This should increase CD sales.

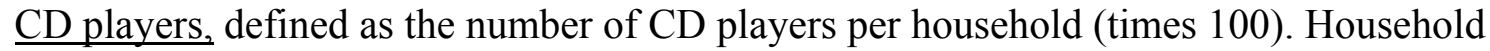
penetration of $\mathrm{CD}$ players captures how easy it is for consumers to copy (positive correlation with CD burners) and enjoy the product (positive correlation with portable music players). Data are presented in Appendix 1.

\footnotetext{
${ }^{7}$ It is quite possible, however, that, at least in the sample period, home broadband access may not capture these substitution patterns across countries if the diffusion process varies across countries (e.g. because of differences in pricing of broadband access, culture etc.).

${ }^{8}$ We used data for 1999 to avoid potential endogeneity issues. We have also run regressions with log differences of MC sales (1998-1999) with similar results, the fit was, as should be expected, however poorer.
} 


\subsection{Model}

We have $n=16$ countries and two periods $t=2000,2001$. Let $y_{i, t}$ denote the sales of CDs in $\log$ units in country $i, i=1, \ldots, n$, at time $t . z_{i, t}$ is the variable that captures internet piracy (in logs). $\mathrm{x}_{i, t}$ is a vector of dimension $k \times 1$ of control variables (also in $\log$ ) in country $i$ at time $t$. To eliminate country specific effects, we write the model in first difference:

$$
y_{i, t}-y_{i, t-1}=\left(\mathrm{x}_{i, t}-\mathrm{x}_{i, t-1}\right)^{\prime} \beta+\alpha\left(z_{i, t}-z_{i, t-1}\right)+\varepsilon_{i, \mathrm{t}}
$$

where $\varepsilon_{i, t}$ has an unobservable variable mean 0 and variance $\sigma^{2}$ that includes factor (5) assumed to be uncorrelated with our explanatory variables, and $\alpha$ and $\beta$ are parameters to be estimated. More specifically, $\alpha$ is the partial effect of online piracy on CD sales.

We do not have data on MP3 downloads, Broadband, and CD players variables for the year 2000. Thus we used these variables in level in the regressions. However, levels are likely to be a good proxy for first differences in that period for most countries: in particular, downloading essentially started in the second half of $1999 .{ }^{9}$

\footnotetext{
${ }^{9}$ In Appendix 2, we present results with a square root transformation of the download and broadband variables account for the fact that increases in MP3 downloads and fast internet connections are proportionally smaller in countries where their levels are high. The estimated coefficients lead to the same partial effect of internet piracy on CD sales. We discuss estimation results for the period 1999-2001 in Appendix 4.
} 


\subsection{Estimation Results}

Table 1 gives our estimation results (ordinary least squares). ${ }^{10}$

\section{Table 1. Estimation results 2000-2001}

\begin{tabular}{|c|c|c|c|c|c|c|c|c|c|c|c|c|c|c|c|c|}
\hline 2000-2001 & (1) & & (2) & & (3) & & (4) & & (5) & & (6) & & (7) & & (8) & \\
\hline & coef. & t-stat & coef. & t-stat & coef. & t-stat & coef. & t-stat & coef. & t-stat & coef. & t-stat & coef. & t-stat & coef. & t-stat \\
\hline GDP & 6.5 & 9.3 & 6.7 & 9.6 & 6.2 & 16.3 & 6.5 & 10.0 & 6.1 & 16.3 & 6.7 & 9.6 & 6.2 & 14.8 & 6.1 & 15.2 \\
\hline Downloads & -0.25 & -8.5 & -0.30 & -4.7 & -0.30 & -8.9 & -0.22 & -4.0 & -0.30 & -6.4 & -0.28 & -3.9 & -0.36 & -5.8 & -0.35 & -5.3 \\
\hline Broadband & & & 0.17 & 0.9 & & & & & -0.03 & -0.2 & 0.16 & 0.8 & & & -0.03 & -0.3 \\
\hline MC sales & & & & & 0.13 & 4.7 & & & 0.14 & 3.4 & & & 0.15 & 4.7 & 0.16 & 3.8 \\
\hline $\mathrm{CD}$ players & & & & & & & 0.0 & -0.6 & & & 0.00 & -0.4 & 0.02 & 1.4 & 0.02 & 1.4 \\
\hline $\mathrm{R}^{2}$ & 0.79 & & 0.81 & & 0.86 & & 0.79 & & 0.86 & & 0.81 & & 0.87 & & 0.87 & \\
\hline Losses & -9 & & -11 & & -11 & & -8 & & -11 & & -11 & & -14 & & -13 & \\
\hline
\end{tabular}

Contrary to Liebowitz (2003) we find a strong positive effect of income (GDP growth) on CD purchases, although this variable may capture other factors related to the domestic economic environment. The coefficient associated with the internet piracy variable is always significantly different from zero (at the 5\% level). Substitution with MC is another important factor influencing CD sales during the period. Broadband penetration and CD players are not significant explanatory variables of CD sales and do not increase the $\mathrm{R}^{2}$ of 0.86 that is fairly high given our small number of explanatory variables and the fact that the model is taken in first differences.

\footnotetext{
${ }^{10} \mathrm{We}$ also ran a set of regressions by interacting internet penetration with the download variable in Appendix 3 . The fit was poorer as an important fraction of heavy music downloaders do not connect from home but rather from work and colleges. Nevertheless the results were in line with those presented in Table 1.
} 
Based on the estimated coefficient associated with the download variable, we can assess the effect of internet piracy on the decline in CD sales (last row of Table 1). In specification (3), the implied loss of CD sales due to MP3 downloads is $11 \%$ worldwide between 2000 and 2001 and is $12 \%$ in the U.S. ${ }^{11}$

\section{Taking a closer look: U.S. Survey data}

In this section, we investigate whether the $12 \%$ loss due to MP3 downloads in the U.S. is compatible with individual consumer behavior.

\subsection{Summary of facts on music downloading in the U.S.}

Survey data gathered for the period 2000-2002 suggest the following stylized facts for the U.S. that are documented in Peitz and Waelbroeck (2003b):

1. 138 million of adults aged 12 and older had access to the internet in 2000 .

2. About $90 \%$ of internet users have access at home, while $10 \%$ can only access form work, colleges or other places in 2001-2002; $25 \%$ of home users have broadband connections and $75 \%$ have dial-up connections.

3. There are essentially two types of music downloaders: $15 \%$ of heavy internet users with broadband connection download music on any given day; only $5 \%$ of light internet users with dial-up connection download on any given day (2001 data).

\subsection{Assessing "internet piracy"}

To assess the effect of music downloads on CD sales we make a number of hypotheses:

\footnotetext{
${ }^{11}$ To obtain these percentages, we multiplied the estimated coefficient $(-0.30)$ by the worldwide average download percentage (37.69) and by the percentage of downloaders in the U.S. (40) respectively.
} 
1. Internet users who download music share downloaded music with friends or resell on the black market; this effect will be referred to as the multiplier of online piracy on offline piracy.

2. Only users who download on a regular basis are a threat to copyright owners.

3. These same users reduce, on average, their net CD demand by 1 to $5 \mathrm{CDs}$.

4. Work internet users have the same downloading behavior as broadband internet users and college students.

5. Home internet users have the same music downloading behavior regardless of whether they only access from home or also from work.

Assumption 1 states that online piracy can have a potential impact on offline piracy because of CD burners. Assumption 2 is reasonable if internet users who only occasionally download music do so to sample new songs. Assumption 3 accounts for different substitution patterns between MP3s and CDs. Assumptions 4 and 5 are made by lack of precise information on these types of internet users.

Based on survey data, we know that $90 \%$ of internet users can connect online from home. Internet users who only download from work or other places (including college students) represent $10 \%$ of the online population and are assumed to have the same behavior as broadband users: $15 \%$ download music on a regular basis. To sum up, among home users, $7.5 \%(=.25 \times .15$ $+.75 \times .05)$ download music on a regular basis. On the other hand, $15 \%$ of work users do so. Thus the total percentage of internet users who are potential copyright "offenders" is $8.25 \%(=.9$ $\times .075+.1 \times .15)$ of the online adult population aged 12 and above $(=138$ millions $)=11.4$ 
million. ${ }^{12}$ Suppose that MP3 downloads substitute for $1 \mathrm{CD}$ and that there are no multiplier effects due to sharing and to offline piracy. Then the lost sales due to music downloads is 11.4 million of units or a $1.21 \%$ decrease in CD sales between 2000 and 2001 . The following table summarizes simulations of lost sales due to piracy for different types of substitution patterns and different multiplier effects.

Table 2. Possible effects of MP3 on CD sales for 2000-2001 (\% of lost sales due to music downloading, 2000-2001)

\begin{tabular}{|c|c|c|c|c|c|c|}
\hline \multirow{7}{*}{ 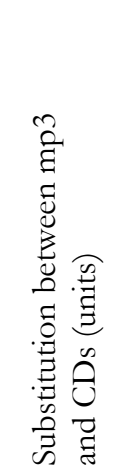 } & & \multicolumn{5}{|c|}{ Offline piracy multiplier } \\
\hline & & 1.00 & 2.00 & 3.00 & 4.00 & 5.00 \\
\hline & 1.00 & 1.21 & 2.42 & 3.62 & 4.83 & 6.04 \\
\hline & 2.00 & 2.42 & 4.83 & 7.25 & 9.66 & 12.08 \\
\hline & 3.00 & 3.62 & 7.25 & 10.87 & 14.50 & 18.12 \\
\hline & 4.00 & 4.83 & 9.66 & 14.50 & 19.33 & 24.16 \\
\hline & 5.00 & 6.04 & 12.08 & 18.12 & 24.16 & 30.20 \\
\hline
\end{tabular}

It is worth noting that in order to obtain an implied loss of $12 \%$, we need to make strong assumptions on the substitution pattern and the multiplier effect. For instance, we could get this percentage if $\mathrm{P} 2 \mathrm{P}$ users reduce their demand by $3 \mathrm{CDs}$ and each pirated $\mathrm{CD}$ reduces legitimate demand by a factor of 3 . We should point out that a value of 3 for the offline piracy multiplier effect is not absurd. For instance, if each CD is burned and shared with two friends (not necessarily directly) who would have purchased the original CD otherwise, the multiplier effect

\footnotetext{
${ }^{12}$ This number is compatible with the 12.5 millions of unique file-sharing network users (mostly Napster) reported
} 
is 3, not an irrelevant scenario. A reduction of $3 \mathrm{CDs}$ however seems large as the average CD consumption per capita was 4.3 units in 2000 (among the 218 millions Americans aged 12 and more); it seems unlikely that heavy downloaders use MP3 downloads as a substitute for $70 \%$ of their average CD consumption. ${ }^{13}$ Therefore we believe that our estimated implied loss (and the estimated partial effect of internet piracy on CD sales) is an upper bound on the effect of internet piracy. However it could be argued that people who download music consume on average a larger number of CDs so that $3 \mathrm{CDs}$ only represent perhaps $30-50 \%$ of their past consumption. The exact substitution pattern between MP3 and CDs and the value of the multiplier effect on offline sales are an important topic for further research. We restricted ourselves here to propose a range of values that are compatible with our implied estimated loss and that can serve as a basis for future work.

\subsection{Forecasts}

To check the validity of our estimated effect of music downloads on CD sales, we forecast on the evolution of CD sales in 2002. Indeed, for the US, we can determine the partial effect of the music download variable on $\mathrm{CD}$ if we assume that the growth in the number of CDs lost to internet piracy is proportional to the number of people downloading music. Table 3 describes the

by comScore Networks for the first quarter of 2001.

${ }^{13}$ IPSOS-REID TEMPO Dec. 2002 asked the following question "Since you initially began downloading music or mp3 files off of the internet, would you say that your Compact Disc purchases have decreased, increased, stayed the same?"; $19 \%$ answered that CD purchases have decreased, $24 \%$ said it increased, while $57 \%$ said they it the same (834 respondants). Jupiter Media Matrix 2002 Report finds that "while file-sharer were 41 percent more likely to increase (music) spending than the average (online) music fan, they were 21 percent more likely to decrease spending." 
evolution of the number of people downloading music. Note the slowdown in music downloads 2002 after the dramatic increase in $2001 .^{14}$

Table 3. Evolution of music downloaders.

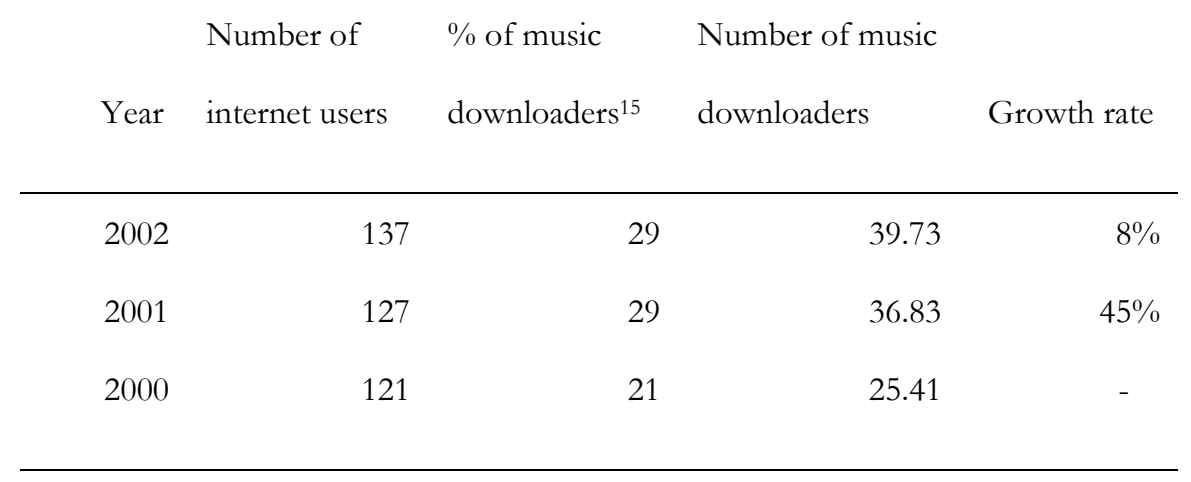

Source: Harris-Interactive (2002), Pew Internet Report (2003) and own calculations

To compute $\alpha$, the partial effect of an increase in the number of people downloading music $\Delta z$, we equalize the total contribution to the decline in CD sales in the U.S.:

$$
\alpha \Delta \mathrm{z}=-12
$$

The number of internet users who download music increased by $45 \%$ between 2000 and 2001 . Thus we have $\alpha=-12$ / $45=-0.27:$ a $1 \%$ increase in the number of people downloading music should roughly trigger a $0.25 \%$ decrease in CD sales. We would like to stress again that this is most likely to be an upper bound on the partial effect of music downloads on future CD sales for

\footnotetext{
${ }^{14}$ This trend is compatible with the slow evolution of the number of P2P users in 2002. IPSOS-REID TEMPO 2002 study reports that the number of persons who have downloaded digital music files from an online file-sharing service in the past 30 days has increased from 9\% April 2002 to 9.5\% in December 2002.

${ }^{15}$ Note that the percentage of $29 \%$ of PEW internet is lower than the $40 \%$ found by IPSOS in the US, the reason is that PEW uses a more restrictive definition of music download: "have you ever downloaded music files to the your computer so that you can play them at any time?", which excludes files that are never or rarely played, such as files sampled from music distribution sites.
} 
two reasons. First, we have already argued that this elasticity implies a strong substitution pattern between MP3s and CDs. Second, there are good reasons to believe that users who have the highest propensity to download music have adopted the P2P technology early, as illustrated by the relatively slow increase in the number of people downloading music in 2002, only two years after the creation of file-sharing technologies.

The effect of internet piracy on CD sales in 2002 is estimated to $-2 \%(=-8 \times 0.25)$ of internet piracy on CD sales. However, CD sales declined by $8.9 \%$ in the US in 2002 , while economic growth picked up to $2.45 \%$. Thus internet piracy alone can only explain $22.5 \%$ of the CD decline in 2002 and is most likely not to be a significant factor in 2003 as the percentage of internet users who download music is reported to have declined further after the series of legal actions undertaken by the RIAA in the summer of 2003. We should stress that in order for internet piracy to fully account for the $8.9 \%$ decline in CD sales, the coefficients associated with internet piracy would have had to be at least 4 times bigger (assuming that GDP has no effects on CD sales). This is unlikely since we already argued that our estimated partial effect of internet piracy is an upper bound.

\section{Conclusion}

We have analyzed the RIAA's claim that music downloads are causing a substantial decrease in CD sales. Our cross-section regression confirms their fear: we find that music downloading could have caused a $10 \%$ reduction in CD sales worldwide in 2001. More work is needed to evaluate the exact substitution rate between CDs and MP3 (including sampling) as well as the value of the multiplier effect of online piracy on offline piracy. Nevertheless, we cannot reject the hypothesis that internet piracy has played a significant role in the CD market in 2001. The 
story for 2002 is different, at least for the US, as the number of people downloading music has only slightly increased. As a matter of fact, our estimates imply a $2 \%$ loss in CD sales due to music downloads, a small number compared to the observed 9\% drop in 2002 in the US. Different factors can explain the current downward trend in CD sales. One such factor may be the effect of the diffusion of fast internet connections on leisure activities. Currently, people are more listening to audio clips and internet radio than downloading music files (see Peitz and Waelbroeck 2003b). While it is not clear how audio streaming will affect record companies in the future (record companies collect royalties on streamed content and clearly online purchase made on the recently launched Apple's ITunes substitute for regular CD purchases), it is only one of the many activities of broadband users. Other forms of digital activities such as instant messaging, looking for news, job and hobby information, creating online content (pictures, web pages), watching video clips and movies, playing online games, purchasing products online and undirected browsing, that are embraced by broadband users, are clearly a substitute to traditional forms of entertainment. Indeed, survey data provide evidence that heavy internet users have reduced the amount of time watching television and listening to music. ${ }^{16}$

As a consequence, the recent legal actions and the development of technical measures of protection of musical CDs carried by copyright owners may be badly motivated. Besides, there are reasons to believe that the music industry might actually benefit from digital distribution. Indeed, numerous surveys (documented in Peitz and Waelbroeck 2003b) highlight the potential sampling role of digital copies. While current P2P technologies are not very good at sampling new music available on P2P networks, since downloader's profiles are not available and cross-

\footnotetext{
${ }^{16}$ See reports by PEW 2002 and Arbitron/Edison Media Research 2003 documented in Peitz and Waelbroeck, 2003 b.
} 
recommendations inexistent, new platforms can be designed to make sampling easier. As a result, labels may benefit from file-sharing because, as Peitz and Waelbroeck (2003c) have argued, they may be able to save on marketing and promotion costs, by letting consumers search for their most preferred music.

\section{References}

Hui, Kai-Lung, and I.P.L. Png (2003), "Piracy and the Legitimate Demand for Recorded Music", Contributions to Economic Analysis \& Policy, Vol. 2: No. 1, Article 11.

Liebowitz, Stan (2003), "Will MP3 Downloads Annihilate the Record Industry? The Evidence so Far," in Gary Libecap (ed.), Advances in the Study of Entrepreneurship, Innovation, and Economic Growth, JAI Press.

Peitz, Martin and Patrick Waelbroeck (2003a), "Piracy of Digital Products: A Critical Review of the Economics Literature," Mimeo.

Peitz, Martin and Patrick Waelbroeck (2003b), "An Economist's Guide to the Technology, Law and Business of Music Distribution," Mimeo.

Peitz, Martin and Patrick Waelbroeck (2003c), "Making Use of File Sharing in Music Distribution," Mimeo. 


\section{Appendix 1. Data}

Our data are summarized below. CD sales and GDP are in log-differences times 100 (i.e. they give percentage change), MC sales, Downloads, Broadband and CD players are in percentage. The last two lines of the table give descriptive statistics of our variables. Note the decrease in CD sales during the period.

\begin{tabular}{|c|c|c|c|c|c|c|}
\hline Country name & CD sales & GDP & Downloads & Broadband & $\mathrm{MC} / \mathrm{CD}$ ratio & $\mathrm{CD}$ players \\
\hline USA & -6.65 & 0.25 & 40 & 9.9 & 13.0 & 259 \\
\hline Japan & -11.20 & -0.58 & 20 & 7.3 & 2.0 & 123 \\
\hline UK & 8.10 & 1.94 & 28 & 1.2 & 10.0 & 148 \\
\hline Germany & -10.73 & 0.57 & 34 & 4.5 & 10.0 & 125 \\
\hline France & 10.78 & 1.82 & 34 & 2.6 & 11.0 & 125 \\
\hline Canada & -7.76 & 1.45 & 44 & 20.5 & 10.0 & 113 \\
\hline Mexico & -7.32 & -0.27 & 35 & 1.9 & 37.0 & 37 \\
\hline Spain & 5.49 & 2.63 & 39 & 3.4 & 21.0 & 88 \\
\hline Italy & -2.85 & 1.76 & 46 & 2.9 & 36.0 & 56 \\
\hline Australia & 12.45 & 3.86 & 37 & 6.0 & 2.0 & 81 \\
\hline Netherlands & -7.93 & 1.26 & 40 & 9.5 & 1.0 & 126 \\
\hline Sweden & 0.76 & 0.82 & 40 & 7.4 & 3.0 & 103 \\
\hline South Korea & 16.66 & 2.99 & 50 & 32.0 & 93.0 & 74 \\
\hline Belgium & -7.44 & 0.75 & 37 & 7.6 & 1.0 & 105 \\
\hline Switzerland & -2.79 & 0.89 & 28 & 3.8 & 4.0 & 157 \\
\hline Taiwan & -22.87 & -1.91 & 51 & 25.0 & 21.0 & 104 \\
\hline Mean & -2.08 & 1.14 & 37.69 & 9.09 & 17.19 & 114.00 \\
\hline Std. dev. & 10.43 & 1.42 & 8.13 & 8.95 & 23.23 & 49.97 \\
\hline
\end{tabular}

Sources: IFPI World Reports 2001 and 2002 (CD sales, MC sales, Broadband, CD players), OECD and Economist Intelligence Unit (GDP), ISPOS-REID (Downloads) 


\section{Appendix 2: Square root transformation}

Here we present results with a square root transformation of the broadband and the download variables.

\begin{tabular}{|c|c|c|c|c|c|c|c|c|c|c|c|c|c|c|c|c|}
\hline \multirow[t]{2}{*}{$2000-2001$} & (1) & & (2) & & (3) & & (4) & & (5) & & (6) & & (7) & \multicolumn{3}{|c|}{ (8) } \\
\hline & coef. & t-stat & coef. & t-stat & coef. & t-stat & coef. & t-stat & coef. & t-stat & coef. & t-stat & coef. & t-stat & coef. & t-stat \\
\hline GDP & 6.6 & 10.1 & 6.6 & 8.3 & 6.3 & 17.6 & 6.6 & 10.3 & 6.1 & 18.4 & 6.6 & 8.3 & 6.4 & 17.2 & 6.1 & 17.0 \\
\hline Downloads & -1.57 & -9.3 & -1.63 & -2.3 & -1.83 & -9.2 & -1.59 & -4.4 & -1.48 & -3.0 & -1.66 & -2.3 & -2.37 & -5.9 & -2.01 & -3.8 \\
\hline Broadband & & & 0.13 & 0.1 & & & & & -0.79 & -0.8 & 0.13 & 0.1 & & & -0.96 & -1.1 \\
\hline MC sales & & & & & 0.11 & 3.7 & & & 0.12 & 3.0 & & & 0.13 & 4.4 & 0.15 & 3.9 \\
\hline $\mathrm{CD}$ players & & & & & & & 0.0 & 0.1 & & & 0.00 & 0.1 & 0.02 & 1.9 & 0.03 & 2.0 \\
\hline$\overline{\mathrm{R}^{2}}$ & 0.80 & & 0.80 & & 0.85 & & 0.80 & & 0.85 & & 0.80 & & 0.86 & & 0.87 & \\
\hline Losses & -10 & & -10 & & -11 & & -10 & & -9 & & -10.1 & & -14 & & -12 & \\
\hline
\end{tabular}

The analysis leads to the relatively similar average implied loss of $11 \%$ worldwide with specification (3). 


\section{Appendix 3: Internet $\times$ download}

Here we use a modified variable for Downloads, namely the original MP3 download variable multiplied by internet penetration as a percentage of the total population (data obtained from the IFPI). However, we miss internet penetration for Switzerland, reducing the total number of observation to 15 (we still leave Brazil out as it is also an outlier with this specification).

\begin{tabular}{|c|c|c|c|c|c|c|c|c|c|c|c|c|c|c|c|c|}
\hline \multirow[t]{2}{*}{$2000-2001$} & (1) & & (2) & & (3) & \multicolumn{3}{|c|}{ (4) } & (5) & \multicolumn{3}{|c|}{ (6) } & (7) & \multicolumn{3}{|c|}{ (8) } \\
\hline & coef. & t-stat & coef. & t-stat & coef. & t-stat & coef. & t-stat & coef. & t-stat & coef. & t-stat & coef. & t-stat & coef. & t-stat \\
\hline GDP & 6.2 & 8.4 & 6.5 & 7.4 & 6.0 & 10.6 & 6.2 & 8.6 & 6.2 & 7.3 & 6.4 & 7.0 & 5.9 & 10.2 & 6.1 & 6.7 \\
\hline Downloads & -0.46 & -5.8 & -0.59 & -2.8 & -0.51 & -4.9 & -0.35 & -2.1 & -0.56 & -2.7 & -0.50 & -1.5 & -0.43 & -2.2 & -0.47 & -1.4 \\
\hline Broadband & & & 0.20 & 0.8 & & & & & 0.10 & 0.4 & 0.17 & 0.6 & & & 0.06 & 0.2 \\
\hline MC sales & & & & & 0.07 & 1.1 & & & 0.05 & 0.7 & & & 0.06 & 1.0 & 0.05 & 0.7 \\
\hline $\mathrm{CD}$ players & & & & & & & 0.0 & -0.8 & & & -0.01 & -0.5 & -0.01 & -0.6 & -0.01 & -0.4 \\
\hline $\mathrm{R}^{2}$ & 0.74 & & 0.76 & & 0.76 & & 0.75 & & 0.76 & & 0.76 & & 0.77 & & 0.77 & \\
\hline Losses & -8 & & -11 & & -9 & & -6 & & -10 & & -8.85 & & -8 & & -8 & \\
\hline
\end{tabular}

The estimated implied loss does not change much, 9\% with specification (3). However the fit is poorer than using the download variable on its own $\left(\mathrm{R}^{2}\right.$ drops from. 0.86 to 0.76$)$. There are two reasons: a reduced number of observations and the inappropriateness of internet penetration to capture heavy music downloaders. 


\section{Appendix 4: 1999-2001}

Here we present results for the period 1999-2001. GDP and MP3 downloads are still significant determinants of CD sales. The effect of the MC to $\mathrm{CD}$ ratio (calculated using 1998 data) is still different from zero with a negative sign, but broadband penetration starts to play a significant role on $\mathrm{CD}$ growth. Clearly, we can not include too many variables with only 16 observations, but nevertheless the estimated implied loss due to music download is 30\% with specification (2) a percentage that is relatively stable across specifications.

\begin{tabular}{|c|c|c|c|c|c|c|c|c|c|c|c|c|c|c|c|c|}
\hline \multirow[t]{2}{*}{ 1999-2001 } & (1) & \multicolumn{3}{|c|}{ (2) } & \multicolumn{2}{|l|}{ (3) } & \multicolumn{2}{|l|}{ (4) } & \multicolumn{2}{|l|}{ (5) } & \multicolumn{2}{|l|}{ (6) } & \multicolumn{2}{|l|}{ (7) } & \multicolumn{2}{|l|}{ (8) } \\
\hline & coef. & t-stat & coef. & t-stat & coef. & t-stat & coef. & t-stat & coef. & t-stat & coef. & t-stat & coef. & t-stat & coef. & t-stat \\
\hline GDP & 7.0 & 4.7 & 7.3 & 11.3 & 8.9 & 9.6 & 7.3 & 5.8 & 8.1 & 9.0 & 7.5 & 13.8 & 8.9 & 9.5 & 7.9 & 8.4 \\
\hline Downloads & -0.99 & -5.0 & -0.80 & -11.5 & -1.09 & -10.7 & -1.17 & -4.9 & -0.88 & -6.1 & -0.93 & -5.9 & -1.14 & -5.9 & -0.95 & -5.1 \\
\hline Broadband & & & -0.87 & -3.8 & & & & & -0.68 & -1.5 & -0.82 & -3.3 & & & -0.70 & -1.6 \\
\hline MC sales & & & & & -0.20 & -3.2 & & & -0.09 & -0.7 & & & -0.19 & -2.6 & -0.06 & -0.5 \\
\hline $\mathrm{CD}$ players & & & & & & & 0.1 & 1.5 & & & 0.03 & 1.1 & 0.02 & 0.4 & 0.02 & 0.8 \\
\hline $\mathrm{R}^{2}$ & 0.66 & & 0.79 & & 0.75 & & 0.69 & & 0.80 & & 0.80 & & 0.75 & & 0.81 & \\
\hline Losses & -37 & & -30 & & -41 & & -44 & & -33 & & -35 & & -43 & & -36 & \\
\hline
\end{tabular}

The total adult population of internet users was 113 million in 1999. However, we do not have data on the percentage of internet users downloading music in 1999. Nevertheless, the implied elasticity of CD sales to internet piracy can be computed if we assume that the percentage of internet users downloading music increased by roughly 40\% between 1999 and 2000, i.e. this percentage was $15 \%(=21 / 1.4)$ in 1999). This conservative scenario gives a total number of music downloaders of $16.95(=0.15 \times 113)$ million in 1999 and a growth rate of $117 \%$ between 1999 and 2001. The implied elasticity of CD sales to internet piracy is $32 / 117$, approximately the same as elasticity of 0.27 obtained for the period $2000-2001$. 


\section{CESifo Working Paper Series}

(for full list see www.cesifo.de)

1057 Carsten Hefeker, Structural Reforms and the Enlargement of Monetary Union, October 2003

1058 Henning Bohn and Charles Stuart, Voting and Nonlinear Taxes in a Stylized Representative Democracy, October 2003

1059 Philippe Choné, David le Blanc and Isabelle Robert-Bobée, Female Labor Supply and Child Care in France, October 2003

1060 V. Anton Muscatelli, Patrizio Tirelli and Carmine Trecroci, Fiscal and Monetary Policy Interactions: Empirical Evidence and Optimal Policy Using a Structural New Keynesian Model, October 2003

1061 Helmuth Cremer and Pierre Pestieau, Wealth Transfer Taxation: A Survey, October 2003

1062 Henning Bohn, Will Social Security and Medicare Remain Viable as the U.S. Population is Aging? An Update, October 2003

1063 James M. Malcomson, Health Service Gatekeepers, October 2003

1064 Jakob von Weizsäcker, The Hayek Pension: An efficient minimum pension to complement the welfare state, October 2003

1065 Joerg Baten, Creating Firms for a New Century: Determinants of Firm Creation around 1900, October 2003

1066 Christian Keuschnigg, Public Policy and Venture Capital Backed Innovation, October 2003

1067 Thomas von Ungern-Sternberg, State Intervention on the Market for Natural Damage Insurance in Europe, October 2003

1068 Mark V. Pauly, Time, Risk, Precommitment, and Adverse Selection in Competitive Insurance Markets, October 2003

1069 Wolfgang Ochel, Decentralising Wage Bargaining in Germany - A Way to Increase Employment?, November 2003

1070 Jay Pil Choi, Patent Pools and Cross-Licensing in the Shadow of Patent Litigation, November 2003

1071 Martin Peitz and Patrick Waelbroeck, Piracy of Digital Products: A Critical Review of the Economics Literature, November 2003 
1072 George Economides, Jim Malley, Apostolis Philippopoulos, and Ulrich Woitek, Electoral Uncertainty, Fiscal Policies \& Growth: Theory and Evidence from Germany, the UK and the US, November 2003

1073 Robert S. Chirinko and Julie Ann Elston, Finance, Control, and Profitability: The Influence of German Banks, November 2003

1074 Wolfgang Eggert and Martin Kolmar, The Taxation of Financial Capital under Asymmetric Information and the Tax-Competition Paradox, November 2003

1075 Amihai Glazer, Vesa Kanniainen, and Panu Poutvaara, Income Taxes, Property Values, and Migration, November 2003

1076 Jonas Agell, Why are Small Firms Different? Managers’ Views, November 2003

1077 Rafael Lalive, Social Interactions in Unemployment, November 2003

1078 Jean Pisani-Ferry, The Surprising French Employment Performance: What Lessons?, November 2003

1079 Josef Falkinger, Attention, Economies, November 2003

1080 Andreas Haufler and Michael Pflüger, Market Structure and the Taxation of International Trade, November 2003

1081 Jonas Agell and Helge Bennmarker, Endogenous Wage Rigidity, November 2003

1082 Fwu-Ranq Chang, On the Elasticities of Harvesting Rules, November 2003

1083 Lars P. Feld and Gebhard Kirchgässner, The Role of Direct Democracy in the European Union, November 2003

1084 Helge Berger, Jakob de Haan and Robert Inklaar, Restructuring the ECB, November 2003

1085 Lorenzo Forni and Raffaela Giordano, Employment in the Public Sector, November 2003

1086 Ann-Sofie Kolm and Birthe Larsen, Wages, Unemployment, and the Underground Economy, November 2003

1087 Lars P. Feld, Gebhard Kirchgässner, and Christoph A. Schaltegger, Decentralized Taxation and the Size of Government: Evidence from Swiss State and Local Governments, November 2003

1088 Arno Riedl and Frans van Winden, Input Versus Output Taxation in an Experimental International Economy, November 2003

1089 Nikolas Müller-Plantenberg, Japan’s Imbalance of Payments, November 2003 
1090 Jan K. Brueckner, Transport Subsidies, System Choice, and Urban Sprawl, November 2003

1091 Herwig Immervoll and Cathal O'Donoghue, Employment Transitions in 13 European Countries. Levels, Distributions and Determining Factors of Net Replacement Rates, November 2003

1092 Nabil I. Al-Najjar, Luca Anderlini \& Leonardo Felli, Undescribable Events, November 2003

1093 Jakob de Haan, Helge Berger and David-Jan Jansen, The End of the Stability and Growth Pact?, December 2003

1094 Christian Keuschnigg and Soren Bo Nielsen, Taxes and Venture Capital Support, December 2003

1095 Josse Delfgaauw and Robert Dur, From Public Monopsony to Competitive Market. More Efficiency but Higher Prices, December 2003

1096 Clemens Fuest and Thomas Hemmelgarn, Corporate Tax Policy, Foreign Firm Ownership and Thin Capitalization, December 2003

1097 Laszlo Goerke, Tax Progressivity and Tax Evasion, December 2003

1098 Luis H. B. Braido, Insurance and Incentives in Sharecropping, December 2003

1099 Josse Delfgaauw and Robert Dur, Signaling and Screening of Workers' Motivation, December 2003

1100 Ilko Naaborg,, Bert Scholtens, Jakob de Haan, Hanneke Bol and Ralph de Haas, How Important are Foreign Banks in the Financial Development of European Transition Countries?, December 2003

1101 Lawrence M. Kahn, Sports League Expansion and Economic Efficiency: Monopoly Can Enhance Consumer Welfare, December 2003

1102 Laszlo Goerke and Wolfgang Eggert, Fiscal Policy, Economic Integration and Unemployment, December 2003

1103 Nzinga Broussard, Ralph Chami and Gregory D. Hess, (Why) Do Self-Employed Parents Have More Children?, December 2003

1104 Christian Schultz, Information, Polarization and Delegation in Democracy, December 2003

1105 Daniel Haile, Abdolkarim Sadrieh and Harrie A. A. Verbon, Self-Serving Dictators and Economic Growth, December 2003

1106 Panu Poutvaara and Tuomas Takalo, Candidate Quality, December 2003 
1107 Peter Friedrich, Joanna Gwiazda and Chang Woon Nam, Development of Local Public Finance in Europe, December 2003

1108 Silke Uebelmesser, Harmonisation of Old-Age Security Within the European Union, December 2003

1109 Stephen Nickell, Employment and Taxes, December 2003

1110 Stephan Sauer and Jan-Egbert Sturm, Using Taylor Rules to Understand ECB Monetary Policy, December 2003

1111 Sascha O. Becker and Mathias Hoffmann, Intra-and International Risk-Sharing in the Short Run and the Long Run, December 2003

1112 George W. Evans and Seppo Honkapohja, The E-Correspondence Principle, January 2004

1113 Volker Nitsch, Have a Break, Have a ... National Currency: When Do Monetary Unions Fall Apart?, January 2004

1114 Panu Poutvaara, Educating Europe, January 2004

1115 Torsten Persson, Gerard Roland, and Guido Tabellini, How Do Electoral Rules Shape Party Structures, Government Coalitions, and Economic Policies? January 2004

1116 Florian Baumann, Volker Meier, and Martin Werding, Transferable Ageing Provisions in Individual Health Insurance Contracts, January 2004

1117 Gianmarco I.P. Ottaviano and Giovanni Peri, The Economic Value of Cultural Diversity: Evidence from US Cities, January 2004

1118 Thorvaldur Gylfason, Monetary and Fiscal Management, Finance, and Growth, January 2004

1119 Hans Degryse and Steven Ongena, The Impact of Competition on Bank Orientation and Specialization, January 2004

1120 Piotr Wdowinski, Determinants of Country Beta Risk in Poland, January 2004

1121 Margarita Katsimi and Thomas Moutos, Inequality and Redistribution via the Public Provision of Private Goods, January 2004

1122 Martin Peitz and Patrick Waelbroeck, The Effect of Internet Piracy on CD Sales: CrossSection Evidence, January 2004 